\title{
FAKTOR YANG MEMPENGARUHI PARTISIPASI MASYARAKAT TERHADAP PROGRAM PENGOLAHAN SAMPAH DI TEMPAT PENGELOLAAN SAMPAH TERPADU-3R (TPST-3R) DESA KESIMAN KERTALANGU KOTA DENPASAR
}

\author{
Gede Asri Rama, Sang Gede Purnama* \\ Program Studi Kesehatan Masyarakat Fakultas Kedokteran Universitas Udayana \\ *Email: sangpurnama@unud.ac.id
}

\begin{abstract}
ABSTRAK
Salah satu model yang diterapkan Kota Denpasar dalam pengelolaan sampah adalah Tempat Pengelolaan Sampah Terpadu 3R (TPST-3R) di Desa Kesiman Kertalangu Kota Denpasar. Beberapa kendala pelaksanaan pengolahan sampah pada TPST- 3R seperti kurangnya partisipasi masyarakat dalam pengelolaan sampah. Tujuan dari penelitian ini adalah untuk mengetahui faktor yang mempengaruhi tingkat partisipasi masyarakat terhadap pengolahan sampah di TPST- 3R. Desa Kesiman Kertalangu kota Denpasar. Rancangan penelitian ini menggunakan penelitian observasional analitik, menggunakan pendekatan kuantitatif dengan desain cross sectional. Tempat penelitian ini adalah di TPST-3R di Desa Kesiman Kertalangu Kota Denpasar, besar sampel dalam penelitian ini adalah 84 kepala keluarga. Hasil penelitian menunjukkan bahwa proporsi partisipasi masyarakat dalam pengelolaan sampah adalah $38.10 \%$. Faktor pengetahuan masyarakat tentang bank sampah dan dukungan tokoh masyarakat berpengaruh nyata terhadap partisipasi masyarakat, dengan OR dan CI masing - masing $(\mathrm{OR}=7.76$; 95\%CI=2.19-27.58; $\mathrm{p}=0.002)$ dan $(\mathrm{OR}=20.26$; 95\%CI=5.10-80.58; $\mathrm{p}<0.001)$.
\end{abstract}

Kata Kunci : Pengelolaan sampah, Bank sampah, Tingkat partisipasi.

\begin{abstract}
One of the models applied by Denpasar City in waste management is the 3R Integrated Waste Management Site (TPST-3R) in Kesiman Kertalangu Village, Denpasar City. Some obstacles to the implementation of waste management at TPST-3R such as the lack of community participation in waste management. The purpose of this study was to determine the factors that influence the level of community participation in waste management in TPST-3R in Kesiman Kertalangu Village, Denpasar. The design of this study used analytic observational research, using a quantitative approach with a cross sectional design. The place of this study was in TPST-3R in Kesiman Kertalangu Village, Denpasar City, the sample size in this study was 84 heads of households. The results showed that the proportion of community participation in waste management was $38.10 \%$. Factors that significantly influence community participation on waste bank are community knowledge and support from the community leaders $(\mathrm{OR}=7.76 ; 95 \% \mathrm{CI}=2.19-27.58 ; \mathrm{p}=0.002)$ and $(\mathrm{OR}=20.26 ; 95 \% \mathrm{CI}=5.10-80.58$; p॰0.001), respectively.
\end{abstract}

Keywords: Waste management, waste bank, level of participation.

\section{PENDAHULUAN}

Sampah menjadi salah satu masalah yang ada di perkotaan, karena timbulan sampah yang ada di perkotaan akan terus meningkat sejalan dengan pertumbuhan penduduk dan meningkatnya kegiatan pembangunan (Thrihadiningrum, 2010). Sampah adalah segala sesuatu yang dihasilkan dari aktivitas manusia dan telah dibuang (Osei-mensah, P. dkk, 2014) atau segala sesuatu yang sudah tidak diinginkan, tidak disenangi dan telah dibuang yang berasal dari aktivitas manusia (Mubarak, W. I dan Chayatin, N. 2009). Berdasarkan data Badan Pusat Statistik Provinsi Bali Kota Denpasar memiliki kepadatan penduduk tertinggi di provinsi Bali yaitu $6.892 \mathrm{jiwa} / \mathrm{km}^{2}$, berdasarkan jumlah penduduk maka diketahui timbulan sampah kota Denpasar pada tahun 2015 mencapai $3.522 \mathrm{~m}^{3}$, salah satu model yang diterapkan Kota Denpasar dalam pengelolaan sampah adalah TPST-3R 
di Desa Kesiman Kertalangu Kota Denpasar. Saat ini, TPST-3R menerapkan dua bentuk pengolahan sampah yaitu dengan penerapan 3R melalui bank sampah dan mengelola sampah organik menjadi pupuk kompos dengan bantuan Japan International Cooperation Agency (JICA).

Dalam pelaksanaan pengolahan sampah yang dilakukan, TPST- 3R mengalami beberapa kendala seperti, kurangnya partisipasi masyarakat, sehingga dapat menghambat keberlanjutan program tersebut (Aryenti, 2011). Partisipasi masyarakat merupakan aspek yang sangat penting dan utama dalam keberhasilan program 3R (Chaerunissa, C., 2014).

Tujuan dari penelitian ini adalah untuk mengetahui faktor yang mempengaruhi tingkat partisipasi masyarakat terhadap pengolahan sampah di TPST- 3R Desa Kesiman Kertalangu Kota Denpasar.

\section{METODE PENELITIAN}

Desain penelitian ini menggunakan penelitian cross sectional analitik. Tempat penelitian ini adalah di TPST-3R di Desa Kesiman Kertalangu Kota Denpasar. Penelitian ini dilakukan mulai dari bulan Januari sampai dengan bulan Mei 2016. Besar sampel dalam penelitian ini adalah 84 kepala keluarga. Pengambilan sampel dengan menggunakan multi stage sampling yaitu dengan menggunakan beberapa teknik sampling. Penentuan jumlah sampel di masing-masing banjar dilakukan secara proporsional dengan mempertimbangkan perbandingan yang seimbang pada masingmasing banjar. Pengumpulan data menggunakan teknik wawancara dengan instrumen kuesioner. Analisis data menggunakan univariat untuk mendapatkan gambaran distribusi frekuensi variabel, bivariat digunakan untuk menggambarkan hubungan antara masing-masing variabel yang kemudian dihitung ukuran asosiasi berupa Odd Ratio (OR) dengan menggunakan uji regresi logistik sederhana yang juga menyertai 95\% Convidence Interval (CI) OR dan nilai $\mathrm{p}$ (p-value) untuk menilai kemaknaan serta Analisis multivariat digunakan untuk melihat hubungan atau pengaruh variabel bebas secara bersamasama (simultan) terhadap variabel tergantung serta untuk mengontrol variabel perancu (confounding). Jenis uji yang digunakan yaitu regresi logistik ganda (multiple logistic regression). Metode seleksi variabel bebas yang digunakan yaitu metode backward.

\section{HASIL}

Karakteristik responden disajikan dalam tabel 1 meliputi, umur, tingkat pendidikan, status bekerja, pengetahuan, sikap, sosialisasi pengolahan sampah, dukungan tokoh masyarakat dan regulasi pembuangan sampah.

Tabel 1. Karakteristik, Pengetahuan, Sikap, Sosialisasi Pengolahan Sampah, Dukungan Tokoh Masyarakat dan Regulasi Pembuangan Sampah
Variabel
$\mathrm{n}=84$
Persentase 


$$
\begin{aligned}
& \text { Umur (mean, SD) } \\
& \leq 45 \text { Tahun }
\end{aligned}
$$$$
>45 \text { Tahun }
$$$$
(46,12.47)
$$

Tingkat pendidikan

$$
\text { - Rendah }
$$

- Tinggi

Status bekerja

- Tidak kerja

- Kerja

90.48
Pengetahuan tentang pengolahan sampah

- Baik

- Buruk

Pengetahuan tentang bank sampah

- Baik

- Buruk

Sikap tentang pengolahan sampah

- Baik

- Buruk

Sikap tentang bank sampah

- Baik

- Buruk

Sosialisasi program pengelolaan sampah

- Ada 26

- Tidak ada

58

Dukungan tokoh masyarakat

- Ada 43

$51.19 \%$

- Tidak ada

Regulasi pembuangan sampah

- Ada

- Tidak ada
Berdasarkan tabel 1, maka dapat diketahui sebagian besar responden berumur > 45 Tahun (53.57\%) dan memiliki tingkat pendidikan tinggi (66.67\%) yang telah bekerja (90.48\%).

Dilihat dari pengetahuan, diketahui bahwa responden memiliki pengetahuan yang baik tentang pengolahan sampah (63.10\%) namun kebanyakan responden memiliki pengetahuan buruk tentang bank sampah (60.71\%).

Tabel tersebut juga menunjukkan bahwa responden memiliki sikap yang baik terhadap pengolahan sampah (89.29\%) namun buruk terhadap bank sampah 
(82.14\%), perbedaan sikap tersebut disebabkan karena tidak ada sosialisasi program pengolahan sampah (69.05\%) pada masing-masing banjar sehingga responden tidak mengetahui apa itu bank sampah.
Pada tabel diatas dapat dilihat bahwa sebagian besar tokoh masyarakat mendukung program pengolahan sampah (51.19\%), hal tersebut dijelaskan dengan diterapkannya regulasi pembuangan sampah (72.62).

Tabel 2. Partisipasi Masyarakat Dalam Program Pengolahan Sampah

\begin{tabular}{ccc}
\hline Variable & $\mathrm{n}=84$ & Persentasi \\
\hline Skor partisipasi (mean, SD) & $(31,16.66)$ & \\
- Berpartisipasi & 32 & 38.10 \\
- $\quad$ Tidak berpartisipasi & 52 & 61.90 \\
\hline
\end{tabular}

Berdasarkan tabel 2, diketahui bahwa hanya 32 responden $(38.10 \%)$ yang berpartisipasi dalam program pengolahan sampah. Sebanyak $61.90 \%$ responden tidak berpartisipasi dalam program pengelolaan sampah dengan alasan tidak mengetahui adanya program, jarak dan sibuk melakukan pekerjaan lain.

Untuk melihat hubungan kemaknaan dari partisipasi masyarakat terhadap program TPST-3R disajikan pada tabel 3.

Tabel 3. Analisis Bivariat Faktor Yang Mempengaruhi Partisipasi Masyarakat Terhadap Program Pengolahan Sampah Terpadu-3R (TPST-3R) Desa Kesiman Kertalangu Kota Denpasar

\begin{tabular}{|c|c|c|c|c|c|c|c|}
\hline \multirow{3}{*}{ Variabel } & \multicolumn{4}{|c|}{$\underline{\text { Partisipasi }}$} & \multicolumn{3}{|c|}{ Analisis bivariate } \\
\hline & \multicolumn{2}{|c|}{$\underline{\mathrm{Ya}}$} & \multicolumn{2}{|c|}{ Tidak } & \multirow[t]{2}{*}{ OR } & \multirow{2}{*}{$\begin{array}{c}95 \% \mathrm{CI} \\
\mathrm{OR}\end{array}$} & \multirow[t]{2}{*}{ p-value } \\
\hline & $\underline{\mathrm{n}}$ & $\underline{\%}$ & $\underline{\mathrm{n}}$ & $\%$ & & & \\
\hline \multicolumn{8}{|l|}{ Umur (mean, SD) } \\
\hline \multicolumn{8}{|l|}{$\leq 45$ Tahun } \\
\hline \multirow[t]{2}{*}{$>45$ Tahun } & 18 & 46.15 & 21 & 52.85 & ref & $0.21-$ & 0.159 \\
\hline & 14 & 31.11 & 31 & 68.89 & 0.53 & 1.28 & \\
\hline \multicolumn{8}{|l|}{ Tingkat pendidikan } \\
\hline - Rendah & 12 & 42.86 & 16 & 57.14 & ref & 0.29 & 0.526 \\
\hline - $\quad$ Tinggi & 20 & 35.71 & 36 & 64.29 & 0.74 & 1.87 & \\
\hline \multicolumn{8}{|l|}{ Status bekerja } \\
\hline - Tidak kerja & 4 & 50.00 & 4 & 50.00 & ref & $0.14-$ & 0.470 \\
\hline - bekerja & 28 & 36.84 & 48 & 63.16 & 0.58 & 2.52 & \\
\hline \multicolumn{8}{|l|}{ Pengetahuan tentang } \\
\hline pengolahan sampah & & & & & & & \\
\hline
\end{tabular}




\begin{tabular}{llccccccc}
\hline - & Baik & 24 & 45.28 & 29 & 54.72 & 2.38 & $0.90-$ & \\
- & Buruk & 8 & 25.81 & 23 & 74.19 & ref & 6.27 & 0.080
\end{tabular}

Pengetahuan tentang

bank sampah

\begin{tabular}{|c|c|c|c|c|c|c|c|}
\hline - Baik & 21 & 63.64 & 12 & 36.36 & 6.36 & $2.40-$ & \\
\hline Buruk & 11 & 21.57 & 40 & 78.43 & ref & 16.85 & $<0.001$ \\
\hline
\end{tabular}

Sikap tentang

pengolahan sampah

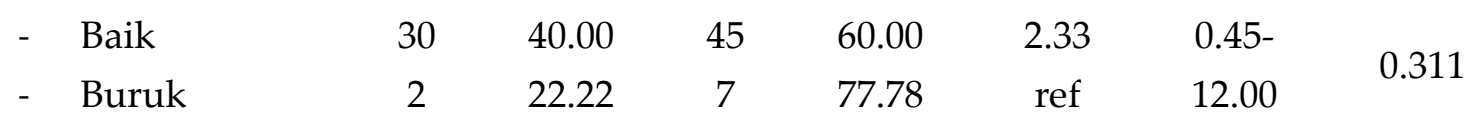

Sikap tentang bank

sampah

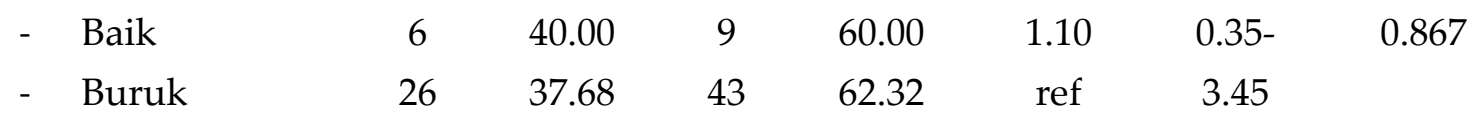

Sosialisasi program

pengelolaan sampah

$\begin{array}{lllccccc}\text { - Ada } & 19 & 73.08 & 7 & 26.92 & 9.40 & 3.24- & <0.001 \\ \text { - Tidak ada } & 13 & 22.41 & 45 & 77.59 & \text { ref } & 27.22 & \end{array}$

Dukungan tokoh

masyarakat

\begin{tabular}{|c|c|c|c|c|c|c|}
\hline Ada & 28 & 65.12 & 15 & 34.88 & 17.27 & $5.16-$ \\
\hline - Tidak ada & 4 & 9.76 & 37 & 90.24 & ref & 57.75 \\
\hline
\end{tabular}

Regulasi

pembuangan

sampah

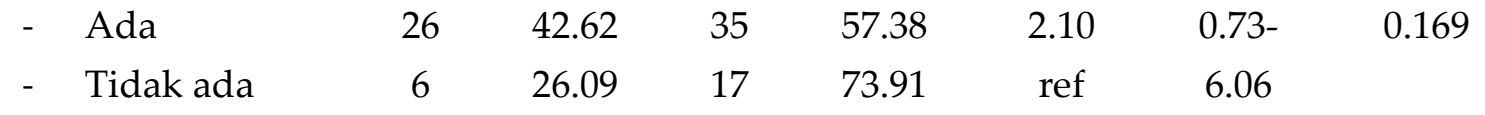

Tabel 4. Analisis Multivariat Faktor Yang Mempengaruhi Partisipasi Masyarakat Terhadap Program Pengolahan Sampah Terpadu-3R (TPST-3R) Desa Kesiman Kertalangu Kota Denpasar

\begin{tabular}{|c|c|c|c|c|c|c|c|}
\hline \multirow{3}{*}{ Variabel } & \multicolumn{4}{|c|}{ Partisipasi } & \multicolumn{3}{|c|}{$\underline{\text { Analisis multivariate }}$} \\
\hline & \multicolumn{2}{|c|}{$\underline{\mathrm{Ya}}$} & \multicolumn{2}{|c|}{ Tidak } & \multirow[t]{2}{*}{ OR } & \multirow{2}{*}{$\begin{array}{c}95 \% \mathrm{CI} \\
\text { OR }\end{array}$} & \multirow[t]{2}{*}{ p-value } \\
\hline & $\underline{\mathrm{n}}$ & $\underline{\%}$ & $\underline{\mathrm{n}}$ & $\%$ & & & \\
\hline \multicolumn{8}{|c|}{ Umur (mean, SD) } \\
\hline$\leq 45$ Tahun & 18 & 46.15 & 21 & 52.85 & 0.54 & $0.17-$ & \multirow{2}{*}{0.310} \\
\hline$>45$ Tahun & 14 & 31.11 & 31 & 68.89 & ref & 1.78 & \\
\hline \multicolumn{8}{|c|}{ Tingkat pendidikan } \\
\hline - Rendah & 12 & 42.86 & 16 & 57.14 & & & \\
\hline
\end{tabular}




\begin{tabular}{ccccc}
\hline $\begin{array}{c}\text { Tinggi } \\
\text { Status bekerja }\end{array}$ & 20 & 35.71 & 36 & 64.29 \\
- Tidak kerja & 4 & 50.00 & 4 & 50.00 \\
- bekerja & 28 & 36.84 & 48 & 63.16
\end{tabular}

Pengetahuan tentang pengolahan sampah

$\begin{array}{llcccc}\text { - } & \text { Baik } & 24 & 45.28 & 29 & 54.72 \\ \text { - } & \text { Buruk } & 8 & 25.81 & 23 & 74.19\end{array}$

Pengetahuan tentang bank sampah

- Baik

- Buruk

Sikap tentang

pengolahan sampah

- Baik

- Buruk
$21 \quad 63.64$

$11 \quad 21.57$
7.76

2.19-

ref

Sikap tentang bank

sampah

$\begin{array}{llcccc}\text { - } & \text { Baik } & 6 & 40.00 & 9 & 60.00 \\ \text { - } & \text { Buruk } & 26 & 37.68 & 43 & 62.32\end{array}$

Sosialisasi program

pengelolaan sampah

$\begin{array}{lllcl}\text { - Ada } & 19 & 73.08 & 7 & 26.92 \\ \text { - Tidak ada } & 13 & 22.41 & 45 & 77.59\end{array}$

Dukungan tokoh

masyarakat

\begin{tabular}{|c|c|c|c|c|c|c|}
\hline Ada & 28 & 65.12 & 15 & 34.88 & 20.26 & $5.10-$ \\
\hline Tidak ada & 4 & 9.76 & 37 & 90.24 & ref & 80.58 \\
\hline
\end{tabular}

Regulasi

pembuangan

sampah

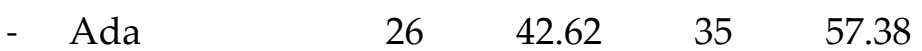

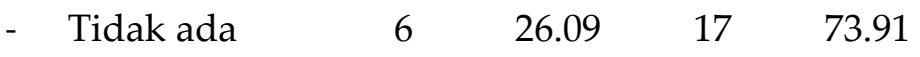

Berdasarkan tabel 3, analisis multivariat dengan memakai uji Logistic Regression dengan menggunakan metode Backward. Variabel bebas yang memiliki nilai $\mathrm{p} \leq 0.25$ pada hasil analisis bivariate selanjutnya diikutsertakan dalam analisis mutivariate. Adapun variabel bebas yang memiliki nilai $\mathrm{p} \leq 0.25$ pada hasil analisis bivariat yaitu meliputi umur, pengetahuan masyarakat tentang pengolahan sampah, pengetahuan masyarakat tentang bank sampah, sosialisasi dan regulasi. Setelah 
dilakukan analisis maka variabel yang bermakna yang mempengaruhi partisipasi masyarakat dalam program pengelolaan sampah yaitu pengetahuan masyarakat tentang bank sampah dan dukungan tokoh masyarakat.

Berdasarkan tabel diatas, diketahui bahwa responden yang memiliki pengetahuan yang baik tentang bank sampah meningkatkan peluang responden untuk berpartisipasi dalam pengolahan sampah 7.76 kali dibandingkan dengan responden yang memiliki pengetahuan yang buruk serta hubungan tersebut juga bermakna secara statistik $(\mathrm{p}=0.002)$.

Berdasarkan variabel dukungan tokoh masyarakat, maka responden yang mendapatkan dukungan tokoh masyarakat memiliki peluang untuk meningkatkan partisipasi terhadap pengolahan sampah 20.26 kali dibandingkan dengan responden yang tidak mendapatkan sosialisasi tentang pengolahan sampah. Dimana, hubungan tersebut juga bermakna secara statistik $(\mathrm{p}<0.001)$.

\section{DISKUSI}

Berdasarkan hasil penelitian ini, diketahui tingkat partisipasi masyarakat masih rendah karena masyarakat masih berada pada tingkat partisipasi pengumpulan sampah atau berpartisipasi secara pasif (therapy) (Wicaksono, 2010). Partisipasi masyarakat dalam pengolahan sampah di TPST Desa Kesiman Kertalangu lebih rendah bila dibandingkan dengan hasil penelitian di Kecamatan Coblong Kabupaten Bandung Provinsi Jawa Barat oleh Apryanti, dkk (2015) mengenai identifikasi faktor utama yang berpengaruh pada partisipasi masyarakat dalam pengelolaan sampah, yaitu partisipasi masyarakat sebesar $65.4 \%$. Rendahnya partisipasi masyarakat di Desa Kesiman Kertalangu sejalan dengan hasil penelitian di FKIP UNLAM Banjarmasin oleh Fahruddin, dkk (2014) yang menyatakan rendahnya partisipasi disebabkan karena akses masyarakat dan pelayanan yang kurang baik, selain itu adanya jasa pengangkutan sampah umum yang lebih praktis membuat masyarakat enggan untuk berpartisipasi pada program pengolahan sampah di TPST Desa Kesiman Kertalangu Kota Denpasar.

Berdasarkan hasil penelitian yang dilakukan dengan variabel pengetahuan masyarakat tentang bank sampah, diketahui bahwa sebagian besar responden memiliki pengetahuan yang buruk tentang bank sampah yaitu $60.71 \%$. Hasil penelitian ini menunjukkan responden yang memiliki pengetahuan baik lebih berpartisipasi dibandingkan dengan responden dengan pengetahuan buruk. Hasil multivariat menunjukkan bahwa responden dengan pengetahuan bank sampah yang baik meningkatkan peluang untuk berpartisipasi dalam pengolahan sampah di TPST Desa Kesiman Kertalangu dan hubungan tersebut bermakna secara statistik $(\mathrm{OR}=7.76$; 95\% $\mathrm{CI}=2.19-27.58 ; \mathrm{p}=0.002$ ). Adanya hubungan bermakna tersebut dapat disebabkan karena responden yang berpengetahuan baik akan memiliki pemahaman terhadap keuntungan yang diperoleh dengan mengikuti bank sampah sehingga lebih banyak yang berpartisipasi dalam pengolahan sampah. Hasil penelitian ini sejalan dengan penelitian yang dilakukan di Kota Medan Provinsi Sumatra Utara oleh Erfinna, dkk (2013), 
dimana variabel pengetahuan tentang bank sampah berhubungan secara signifikan dengan partisipasi masyarakat, dimana semakin tinggi pengetahuan masyarakat tentang bank sampah maka semakin tinggi tingkat partisipasi masyarakat dalam implementasi program pengelolaan sampah $(\mathrm{p}=0.002)$.

Berdasarkan hasil analisis tersebut, berkaitan dengan besarnya pengaruh pengetahuan masyarakat tentang bank sampah terhadap partisipasi program pengolahan sampah maka penting untuk meningkatkan sosialisasi terkait bank sampah. Hal ini disebabkan karena pengetahuan mengenai bank sampah yang baik akan meningkatkan pengetahuan masyarakat mengenai bagaimana mekanisme bank sampah serta apa saja yang dapat ditabung di bank sampah.

Selain variabel pengetahuan tentang bank sampah, variabel lain yang masuk ke dalam model adalah dukungan tokoh masyarakat, proporsi responden yang menyatakan adanya dukungan tokoh masyarakat yang berpartisipasi dalam program pengolahan sampah lebih besar dari pada proporsi responden yang menyatakan tidak ada dukungan tokoh masyarakat yaitu sebesar 65.12\%. Berdasarkan hasil multivariat, diketahui bahwa adanya dukungan tokoh masyarakat berpeluang untuk meningkatkan partsipasi masyarakat dalam pengolahan sampah dan hubungan tersebut juga bermakna secara statistik $(\mathrm{OR}=20.26$; 95\% CI=5.10-80.58; $\mathrm{p}=<0.001)$. Adanya hubungan bermakna tersebut menunjukkan bahwa masyarakat akan lebih termotivasi bila tokoh masyarakat yang memberikan dukungan, selain itu tokoh masyarakat juga lebih dipercaya oleh masyarakat setempat sehingga peningkatan partisipasi dalam pengolahan sampah akan terjadi. Hasil penelitian ini sejalan dengan penelitian yang di lakukan di Kabupaten Boalemo Gorontalo oleh Surotinojo, (2009) dimana tokoh masyarakat mempengaruhi partisipasi masyarakat. Maka dari itu, dukungan dari tokoh masyarakat perlu ditingkatkan baik dari informasi, akses dan arahan yang tepat tentang cara pengolahan yang benar.

\section{SIMPULAN}

Tingkat partisipasi masyarakat Desa Kesiman Kertalangu terhadap program pengolahan sampah di tempat pengolahan sampah terpadu (TPST) Desa Kesiman kertalangu masih rendah yaitu sebesar $38.10 \%$, kebanyakan masyarakat Desa Kesiman Kertalangu masih beradapada tingkat therapy. Dimana pada tingkat ini masyarakat hanya berpartisipasi secara pasif yaitu hanya mengumpulkan sampah.

Berdasarkan hasil analisis regresi logistik, didapatkan faktor-faktor yang mempengaruhi partisipasi masyarakat terhadap program pengolahan sampah di Desa Kesiman Kertalangu adalah pengetahuan masyarakat tentang bank sampah $(\mathrm{p}=0.002)$ dan dukungan tokoh masyarakat $(\mathrm{p}<0.001)$.

\section{DAFTAR PUSTAKA}

Apryanti, C., dkk.(2015). Identifikasi Faktor Utama yang Berpengaruh pada Partisipasi Masyarakat dalam Pengelolaan Sampah di Kecamatan Coblong, Kota Bandung. Jurnal 
Perencanan Wilayah dan Kota A SAPPK, 4 (3): 885-894.

Aryenti.(2011). Peningkatan Partisipasi Masyarakat Dalam Pengelolaan Sampah Dengan Cara 3R (Reduce, Reuse, Recycle) Di Lingkungan Permukiman

Ditinjau Dari Segi Sosial Ekonomi Masyarakat. Jurnal Permukiman, 6 (2): 7583.

Badan Pusat Statistik. (2015). Kota Denpasar Dalam Angka. Denpasar: Badan Pusat Statistik Provinsi Bali.

Chaerunissa, C.2014. Partisipasi Masyarakat

Dalam Program Penyediaan Air Minum

Dan Sanitasi Berbasis Masyarakat (Pamsimas) Di Kabupaten Brebes. POLITIKA, 5 (2): 1-15.

Erfinna, T. F., dkk.(2013). Hubungan Karakteristik Dengan Partisipasi Masyarakat Dalam Pengelolaan Sampah di Lingkungan III dan V Kelurahan Bagan Deli Kecamatan Medan Belawan Tahun 2012. Lingkungan dan Kesja, 2 (2):18.

Fahruddin, A. S., dkk.(2014). Persepsi Nasabah Terhadap Bank Sampah Gerakan Peduli Sampah Fkip Unlam Banjarmasin. Jurnal Pendidikan Geografi : 136-148.

Mubarak, W. I., dkk, N.(2009). Ilmu Kesehatan Masyarakat Teori dan Aplikasi. Jakarta: Salemba Medika.

Osei-mensah, P., $\quad$ dkk.(2014). Characterization Of Solid Waste In The Atwima-Nwabiagya District Of The Ashanti Region, Kumasi-Ghana. International Journal of Waste Management and Technology, 2 (1): 1-14.

Surotinojo, I.(2009). Partisipasi Masyarakat Dalam Program Sanitasi Oleh
Masyarakat (Sanimas) Di Desa Bajo Kecamatan Tilamuta Kabupaten Boalemo. Tesis. Program Pascasarjana Magister Teknik Pembangunan Wilayah Dan Kota Universitas Diponegoro. Semarang

Thrihadiningrum, Yulinah. 2010. MDGs Sebentar Lagi Sanggupkah Kita Menghapus Kemiskinan di Dunia. Jakarta: PT Gramedia. 